FINAL REPORT

U.S. Department of Energy Grant No. DE-FG02-02ER63480

Reporting period: 9/1/02-8/31/03

Massachusetts General Hospital, Boston, Massachusetts

Anna-Liisa Brownell, phone \# 617-726-3807, fax \# 617-726-5123

\title{
Novel in vivo imaging techniques for trafficking the behavior of subventricular zone neural stem cells (SVZSC) and SVZSC induced functional repair
}

We have been funded for one year starting on September 2002 to investigate trafficking of subventricular zone (SVZ) cells. During the one year period we have established a cell-research laboratory to grow and label cells for imaging studies; developed cell labeling techniques; developed transplantation techniques and performed 36 transplantation procedures with radiolabeled and/or iron labeled cells; conducted longitudinal follow up studies of trafficking of the cells and end point histochemical evalution. During this period, we have learned that in addition to radiopharmaceutical techniques the basic biological issues are also important to enhance cell survival after complicated labeling procedures. Similarly, immunohistochemical analyses are important to investigate the fate of the cells, since we cannot see inside the cell with any in vivo imaging technique in the living subject. Immunohistochemical evalution provides information, which can be utilized also in developing cell-friendly radiolabeling techniques. In addition, the studies conducted during one-year period have shown that it is important to obtain data of the overall mobility of the particular cell type and design techniques to detect trafficking based on that data. Trafficking of fast mobile cells can be investigated with direct labeling of the cells. However, cells that move slowly, need to have another approach. One option is to introduce a reporter gene into the cell and develop radiolabeled ligand, which can be repeatedly used to detect it and obtain timedependent migration of the cells.

We submitted a renewal application six months after initiating this project to address these questions. The renewal application did not get funded, since we did not have preliminary data to show that we can label or introduce a reporter gene into the cell. Introduction of the reporter gene was not included in the original application, but based on our experience, we know that it is a way to proceed. During the past three months we have developed techniques to introduce a reporter gene into the cells, and correspondingly developed radiopharmaceutical techniques to image it. In addition, we have conducted preliminary studies with radiolabeled cells and tumor bearing animals. These techniques can be introduced to any kinds of cell functions.

In the original grant application we acknowledged that in vivo monitoring of the migration of the transplanted progenitor cells is a challenging task for many reasons: the migration of the cells is dependent on the administration route and tissue environment; the migration rate is slow (days and weeks) and distances are small ( $\mathrm{mm}$ or $\mathrm{cm}$ ); labeling of the cells with high specific radioactivity without damaging them with chemicals or 
radiation dose is challenging and super high resolution and high sensitivity is required from imaging instruments to obtain meaningful data.

After one year we can realize that we have overcome the above-mentioned obstacles and we have labeled rat progenitor cells and tested them in in vitro conditions and used them for in vivo imaging studies. In vivo imaging has been conducted with an in-house built super high-resolution positron emission tomograph as well as a commercial high-resolution primate microPET (Concord Microsystems) and with highresolution magnetic resonance scanner (9.4T Brucker). In addition, the in vivo imaging techniques have been compared and correlated with post mortem immunohistochemical evaluation as an aim to investigate trafficking of the cells and the effect of the injection sites on the outcome of the transplanted cells. These experiments are carried out in normal and 6-hydroxydopamine (6-OHDA) lesioned rats.

The specific goals of this research project were to develop imaging techniques for non-invasive, long-term tracking of progenitor cells with a perspective that in the future, clinical trials using stem and progenitor cells to replace dysfunctional endogenous cells will require this ability to follow the cells in living tissue over time. These methods should allow studying of cell trafficking, specifically movement and fate of transplanted cells.

\section{Experimental cell work}

Cells: In the past 12 months we have utilized in these studies rat PC 12 (pheochromocytoma cells, obtained from ATCC, Manassas, VA) and rat SVZ subventricular zone cells (courtesy of Robert Gross, Emory University, Atlanta, GA). These cell lines were selected as PC12 cells rapidly proliferate and can be induced by specific growth factors to become dopaminergic, while SVZ cells are rapidly migrating and are neuronal progenitors.

PC12 cells: PC12 cells resemble adrenal chromaffin cells. However, when cultured in the presence of nerve growth factor (NGF), PC12 cells differentiate to resemble sympathetic neurons. PC12 cells release, depending on the conditions, dopamine, norepinephrine and acetylcholine and contain $\mathrm{Na}^{+}, \mathrm{K}^{+}$and $\mathrm{Ca}^{2+}$ channels and other membrane receptors, including receptors coupled to G-proteins (Shafer 1991), (Ng 2002). SVZ cells: SVZ cells, isolated from the lining of the lateral ventricle in the forebrain of adult rats, are a rapidly migrating population of neuronal stem cells (Kakita 1999), (Picard-Riera 2002) that are multipotent. In vitro, these cells can differentiate into neurons, astrocytes, and oligodendrocytes according to the culture conditions (Gritti 1996), (Lois 1993). In vivo, these cells will multiply, migrate through the rostral migratory stream to the olfactory bulb to replace periglomerular and granular neurons (Goldman 1998), (Lois 1994). SVZ cells can be induced to divide more rapidly and differentiate into astrocytes or neurons, replacing damaged or dead cells lost by injury. Immunohistochemical studies have showed that transplanted SVZ cells will migrate into specific target locations, proliferate and express neuronal or astrocytic marker (Peng 2002). 
PC 12 cells and SVZ cells were grown in supplemented media at $37^{\circ} \mathrm{C}$ and $5 \% \mathrm{CO}_{2}$. PC 12 cells were maintained in Ham's F12K media (ATCC) supplemented with $15 \%$ horse serum and $2.5 \%$ fetal bovine serum. SVZ cells were grown in CellGro media (1:1 DMEM:F12; Gibco, Invitrogen Corporation) with $0.5 \mathrm{mM}$ glutamine, $1: 100 \mathrm{~N} 2$ and 10 $\mathrm{ng} / \mathrm{ml} \mathrm{EGF}$.

Labeling of cells with ${ }^{18}$ F-FDG $\left({ }^{18}\right.$ F-2-fluorodeoxy-D-glucose): PC 12 and SVZ were labeled with ${ }^{18} \mathrm{~F}$-FDG according the method, earlier developed in the laboratory (Melder, D. et al. 1994). Rate of ${ }^{18} \mathrm{~F}-\mathrm{FDG}$ uptake and wash-out was determined by counting activity in pellet and supernatant over time. PC 12 cells exhibited linear uptake in label over a 60 min incubation (Figure 1), retaining $66 \%$ of the activity 90 minutes after removal of label (Figure 3). Average cell viability (trypan blue exclusion) was $46 \%$ during the labeling period (Figure 4). SVZ cells exhibited an increase in uptake of label within a 60 min incubation (Figure 2), retaining $43 \%$ of label 90 minutes after removal of label (Figure 4). Average cell viability was 30\% during the labeling period.
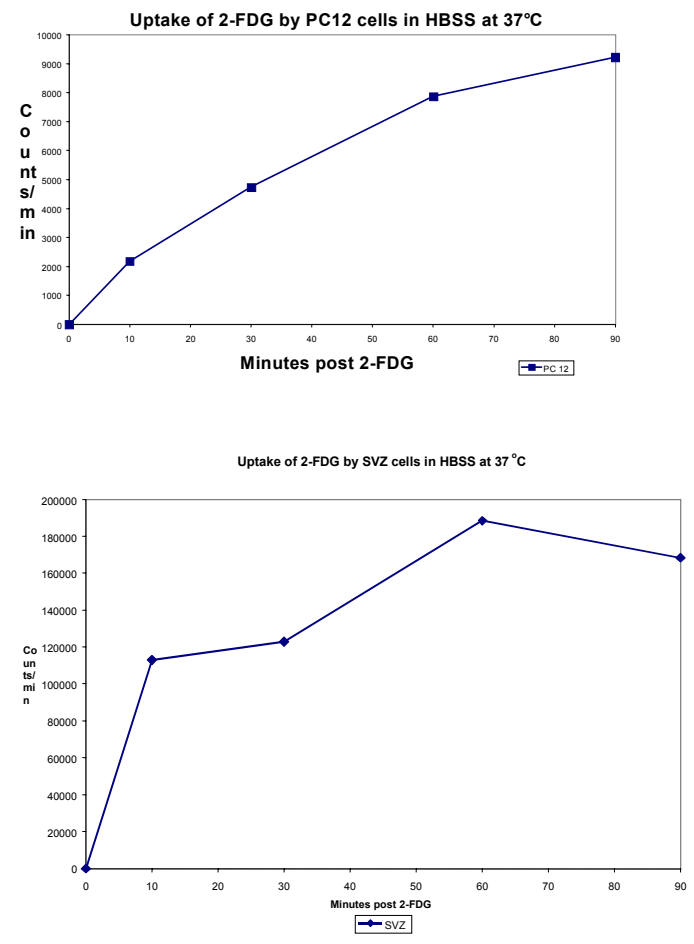

Retension of 2-FDG in PC 12 and SVZ cells

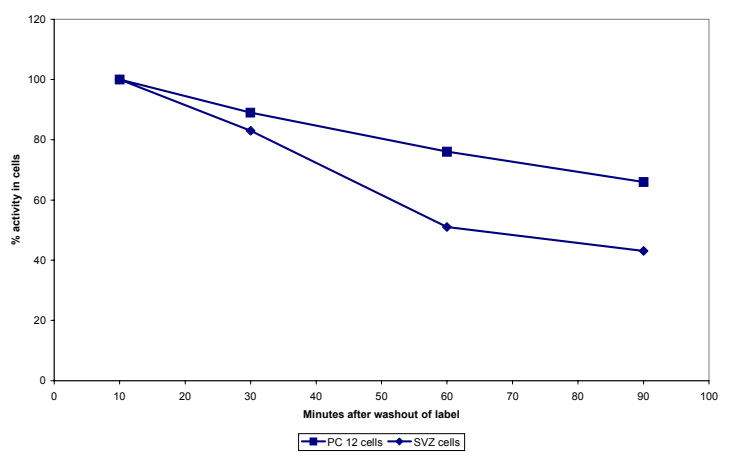

Figure 1. Uptake of ${ }^{18} \mathrm{~F}-\mathrm{FDG}$ by PC12 cells in HBSS at $37^{\circ} \mathrm{C}$. Samples of the cell suspension $(6 \mathrm{x}$ $10^{7}$ ) were removed and washed twice with warm HBSS prior to counting. Each sample was centrifuged and the counts per minute in the pelleted cells determined. Each point indicates the mean \pm SD of triplicate samples.

Figure 2. Uptake of ${ }^{18} \mathrm{~F}-\mathrm{FDG}$ by SVZ cells in HBSS at $37^{\circ} \mathrm{C}$. Samples of the cells suspension $\left(0.6 \times 10^{6}\right)$ were removed and washed twice with warm HBSS prior to counting. Each sample was centrifuged and the distribution of the activity in the supernatant and pellet determined as \% activity in the fraction. Each point indicates the mean \pm SD of triplicate samples.
Figure 3. Retension of ${ }^{18} \mathrm{~F}-\mathrm{FDG}$ label in SVZ and PC12 cells in HBSS at $37^{\circ} \mathrm{C}$. Samples of the cells suspension $\left(0.6 \times 10^{6}\right)$ were incubated for 30 minutes with label, then centrifuged and supernatant removed. Cells were washed twice with warm HBSS and the pellet resuspended in HBSS. Samples were removed after washout and the amount of activity in the pellet of cells determined. 


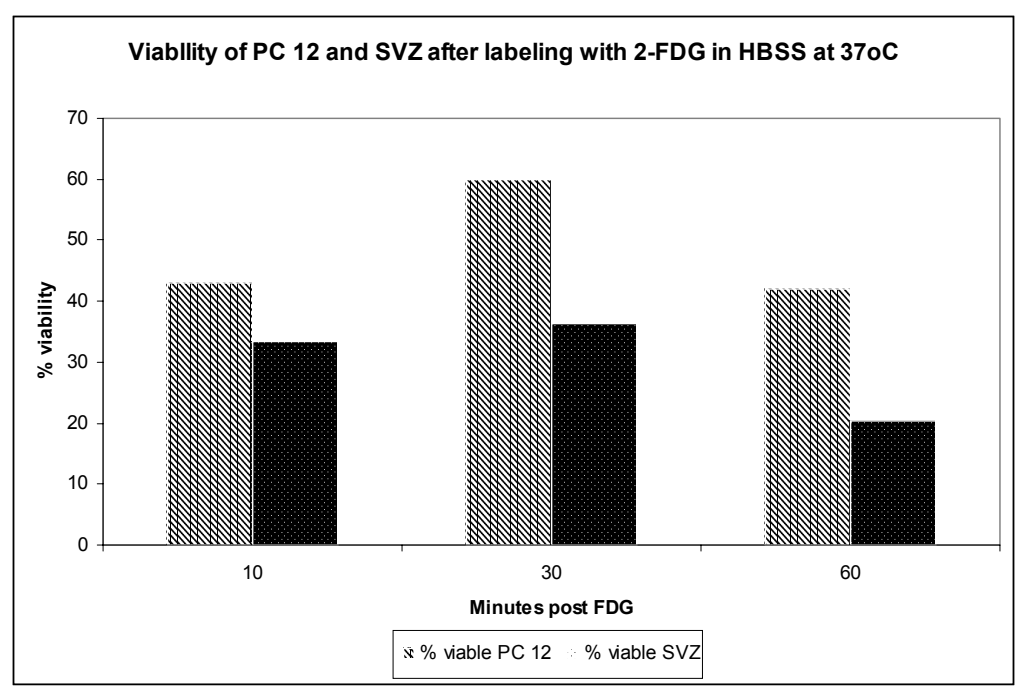

Figure 4. Viability of cells was assessed by dye exclusion ( $0.4 \%$ trypan blue) .

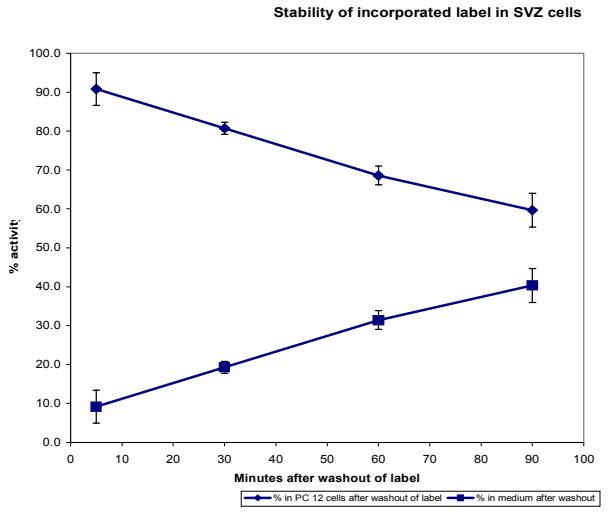

Figure 5. Stability of ${ }^{18}$ F-FDG label in SVZ and PC 12 cells in $\mathrm{HBSS}$ at $37^{\circ} \mathrm{C}$. Samples of the cells suspension $\left(0.6 \times 10^{6}\right)$ were incubated for 30 minutes with label, then centrifuged and supernatant removed. Cells were washed twice with warm HBSS and the pellet resuspended in HBSS. Samples were removed after washout and the distribution of the activity in the supernatant and pellet determined as \% activity in the fraction. Each point indicates the mean \pm SD of triplicate samples.

Uptake of superparamagnetic iron oxide (SPIO): PC 12 and SVZ cells were labeled with superparamagnetic iron oxide (Bulte 2002) for MR imaging. After 48 hours in labeling medium (ferumoxide-poly-L-lysine complex), cells were plated into poly-lysine coated chamber slides for 24 hours, fixed with $4 \%$ glutaraldehyde, and stained for iron (Figures 6 and 7). Iron uptake by cells was determined by staining with Prussian blue (Accustain, Sigma Diagnostics, St-Louis, MO). Intracellular iron deposits stained blue in the presence of potassium ferrocyanide and the cytoplasm of cells was counterstained pink with pararosanaline. PC 12 and SVZ cells stained for iron, showed deposits primarily localized to the cortical regions of the cells although intracytoplasmic deposits of iron were seen in endoplasmic regions.
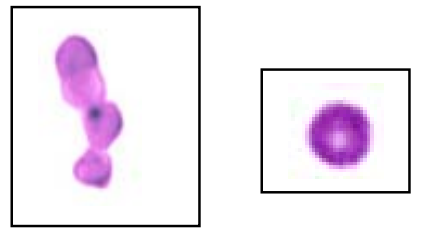

Figure 6. PC 12 cells labeled with SPIO for $48 \mathrm{hr}$, cultured in polylysine coated chamber slides for 24 hr., fixed and stained for iron (Prussian blue).

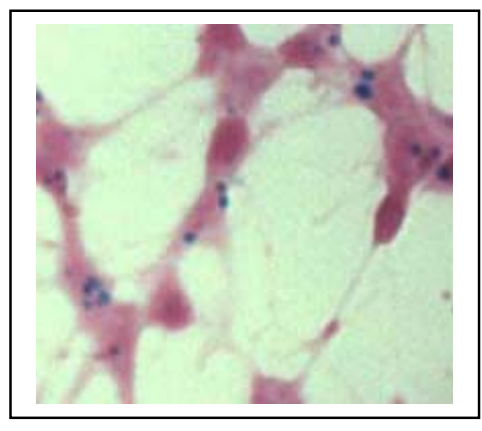

Figure 7. SVZ cells labeled with SPIO for $48 \mathrm{hr}$ and cultured in the same way as PC12 cells. 


\section{In vivo imaging of radiolabeled cells}

Technical aspects of in vivo imaging can be divided into imaging system related and experimental object related aspects. Imaging system related aspects are resolution and sensitivity. Resolution is an important factor for the imaging system, because it sets the limit for the size of the object to be detected (Brownell 1989) as well as effects on quantification through partial volume effects (Hoffman 1979). Sensitivity is a factor, which affects detection efficiency, temporal resolution and image quality (Brownell 1989).

Experimental object related aspects include volume of the injected activity, injected mass of radiolabeled ligand and specific radioactivity of probes. The specific activity can be critical in small objects that are mass limited. To ultimately achieve adequate signal per noise ratio in millimeter resolution level in reconstructed images from mass limited probes, it is likely that specific radioactivity has be increased by an order of two magnitudes. To test this aspect on the cell survival we used extremely high specific activity $(>1500 \mathrm{mCi} / \mu \mathrm{Ci})$ in the labeling with ${ }^{18} \mathrm{~F}-\mathrm{FDG}$.

Experimental animal models: In the field of neuroscience, many researchers prefer rats as experimental animals. This is partly for practical reasons related to the ease of surgical manipulation of the rat brain. In addition, historically there exists a large knowledge of both the anatomy and function of the rat brain. In these experiments we used in addition to normal rat, a 6-hydroxydopamine lesioned rat model of Parkinson's disease. We had earlier experience with this rat model including transplantation experiments (Brownell 1998), (Cicchetti 2002).

6-OHDA lesion: Rats (female Spraque-Dawley, 300-350 g) were anesthetized with ketamine $(100 \mathrm{mg} / \mathrm{kg}$ i.p. $)$ and xylazine $(6 \mathrm{mg} / \mathrm{kg}$ i.m. $)$. To restrict effect of 6-OHDA on the dopaminergic neurons, animals received desipramine $(20 \mathrm{mg} / \mathrm{kg}$ i.p.) $30 \mathrm{~min}$ prior to the 6-OHDA injection. The animals were placed in a Kopf Instrument stereotactic frame and receive an unilateral injection of 6-OHDA $(8 \mathrm{ug} / 2 \mathrm{ul})$ into the medial forebrain bundle (coordinates: AP -4.5; ML +1.2, DV -7.6). Transplantation studies were conducted 2-3 months after 6-OHDA lesioning.

Transplantation: Before transplantation cell viability was assessed by acridine orange/ethidium bromide cell dye exclusion. Rats were transplanted in one of the following anatomical locations: the rostral migratory stream (RMS) or the striatum. Injections were made into the RMS: $\mathrm{AP}=+3.7 \mathrm{~mm} ; \mathrm{L}=+1.5 \mathrm{~mm}$ from bregma, and $\mathrm{V}=$ $5.0 \mathrm{~mm}$ from dura; the toothbar was set at $-2.3 \mathrm{~mm}$; the right striatum: $\mathrm{AP}=+0.5 \mathrm{~mm}$; $\mathrm{L}=$ $+3.0 \mathrm{~mm}$ from bregma, and $\mathrm{V}=-4.5 \mathrm{~mm}$ from dura; the toothbar was set at $-2.5 \mathrm{~mm}$. The labeled cell suspension (either ${ }^{18}$ F-FDG or iron oxide labeled PC12 or SVZ cells) was diluted to a concentration of 100,000 cells $/ \mu 1$ and $1 \mu 1$ was injected into the target in the host brain using a $10 \mu 1$ Hamilton syringe and a $45^{\circ}$ beveled needle. The cell solution was injected at a rate of $1 \mu 1$ per 2 minutes, followed by a 2 min wait before withdrawal of the needle.

PET imaging studies: For the imaging studies rats were anesthetized with halothane (1.5-2\% with $3 \mathrm{~L} / \mathrm{min}$ oxygen flow). Tail vein and artery were catheterized for injection of labeled receptor ligands and drawing of blood samples needed for quantification. In the imaging studies of trafficking of the radiolabeled cells, no tail cathetrization was needed. 
The rat was adjusted into the headholder and head was straight with the ear and eyebars.

PET imaging studies were conducted in 18 rats immediately after transplantation: 6 rats transplanted with ${ }^{18} \mathrm{~F}$-FDG labeled PC12 cells into the rostral migratory stream; 6 rats transplanted with ${ }^{18} \mathrm{~F}$-FDG labeled PC12 cells into the striatum; 3 rats transplanted with ${ }^{18}$ F-FDG labeled SVZ cells into the rostral migratory stream; and 3 rats transplanted with ${ }^{18}$ F-FDG labeled SVZ cells into the striatum. The rats were imaged with the inhouse built high resolution MicroPET (Figure 8) and a commercial MicroPET, P4, (Concord Microsystems) (Figure 9). The commercial MicroPET allows 3D-imaging and localization of migration in all possible directions. In-house built system is a single ring device and allows localization in a plane. To obtain maximum information of migration, the imaging was done first with the Concord MicroPET to obtain overall concept of mobility and then the anesthetized animal was removed into the in-house made system to get higher resolution image of the details.

MRI studies: Rats were imaged either at a $4.7 \mathrm{~T}$ or a $9.4 \mathrm{~T}$ MR scanner (Brucker, Billerica, MA) immediately after transplantation with the superparamagnetic oxide labeled cells and the imaging sessions were repeated 1, 3, 7, 14, 28 and 40 days after grafting. For imaging studies rats were anesthetized with $1 \%$ halothane with ogygen flow of $3 \mathrm{~L} / \mathrm{min}$ and body temperature was maintained at $37^{\circ} \mathrm{C}$ via a motor-controlled warm water blanket. Brain images were obtained by using high-resolution T1-weighted, T2weighted, proton-density and gradient echo sequences (in-plane resolution 0.19 X 0.19 $\mathrm{mm} 2$ with $1.0 \mathrm{~mm}$ slice thickness).

Longitudinal MR imaging studies were conducted in 18 rats, transplanted with iron oxide labeled cells: 3 rats with PC12 cells into the rostral migratory stream (Figure 11), 3 rats with PC12 cells into the striatum (Figure 10), 6 rats with SVZ cells into the rostral migratory stream (Figure 12), and 6 rats with SVZ cells into the striatum (Figure 12).

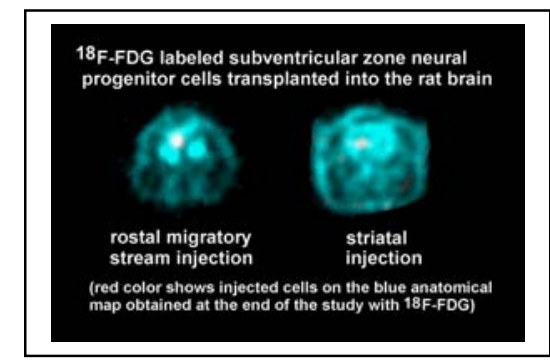

Figure 8.Localization of the cells.

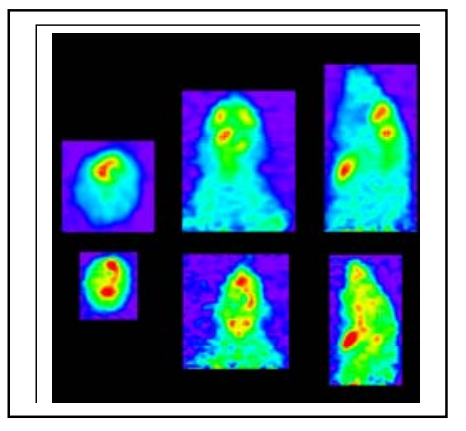

Figure 9. (upper row) PET studies of dopamine transporters by ${ }^{11} \mathrm{C}-\mathrm{CFT}$ and (lower row) inflammation imaged by ${ }^{11} \mathrm{C}$ PK11195, indicator of activated micro glia, in the rat 7 (Fig. 10) 15 days after transplantation. Large tumor has blocked striatal dopaminergic function and caused large local inflammation.

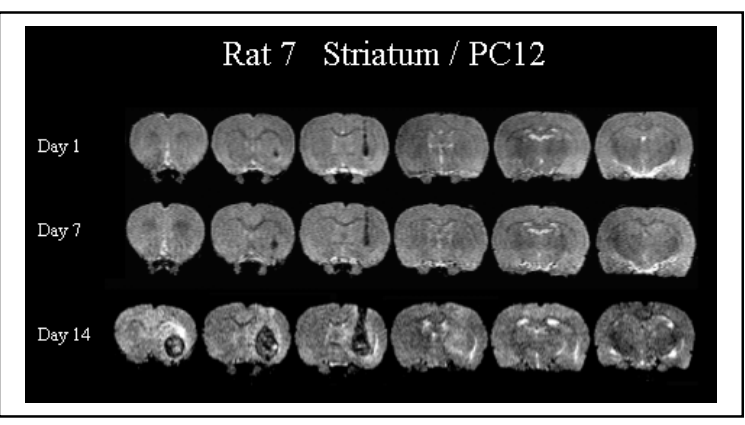

Figure 10. PC 12 cells administered into the striatum grew to a massive tumor.

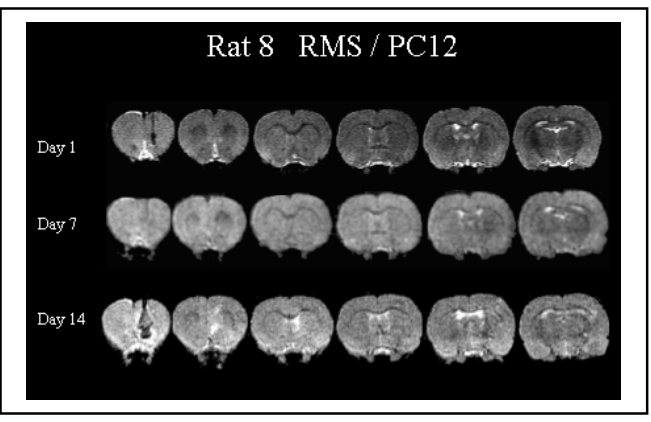

Figure 11. PC12 cells administered into the rostral migratory stream did not grow as fast as administered into the striatum. 

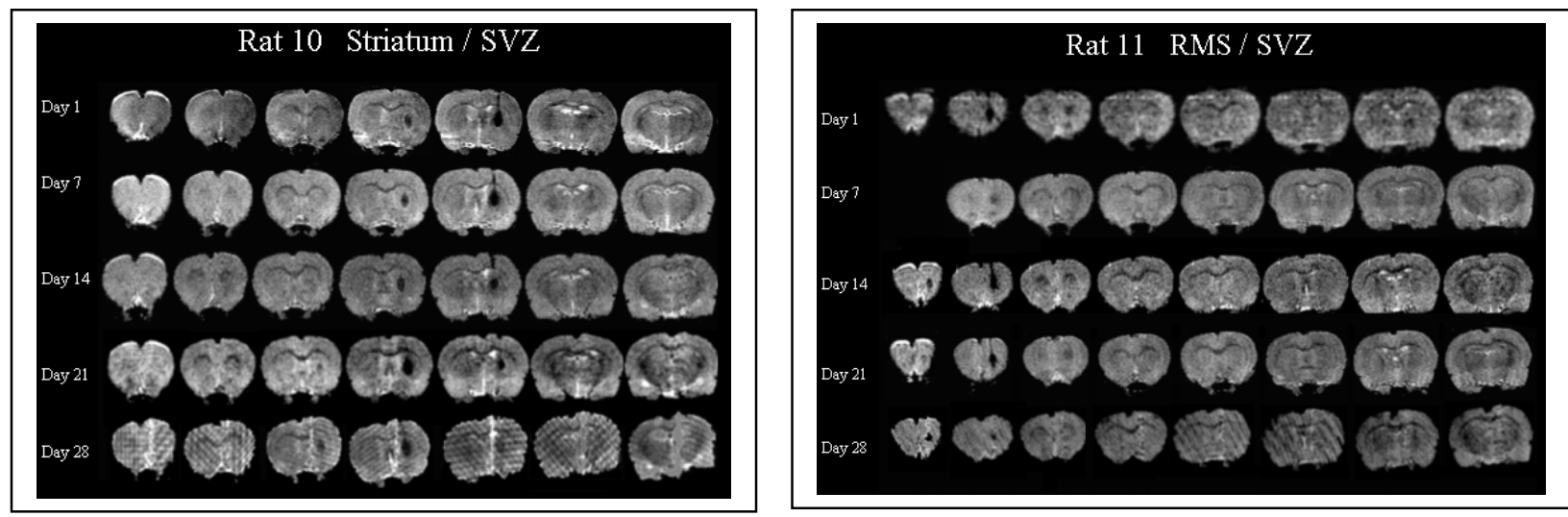

Figure 12. Follow up studies of iron oxide labeled SVZ cells, transplanted into the striatum or the rostral migratory stream.
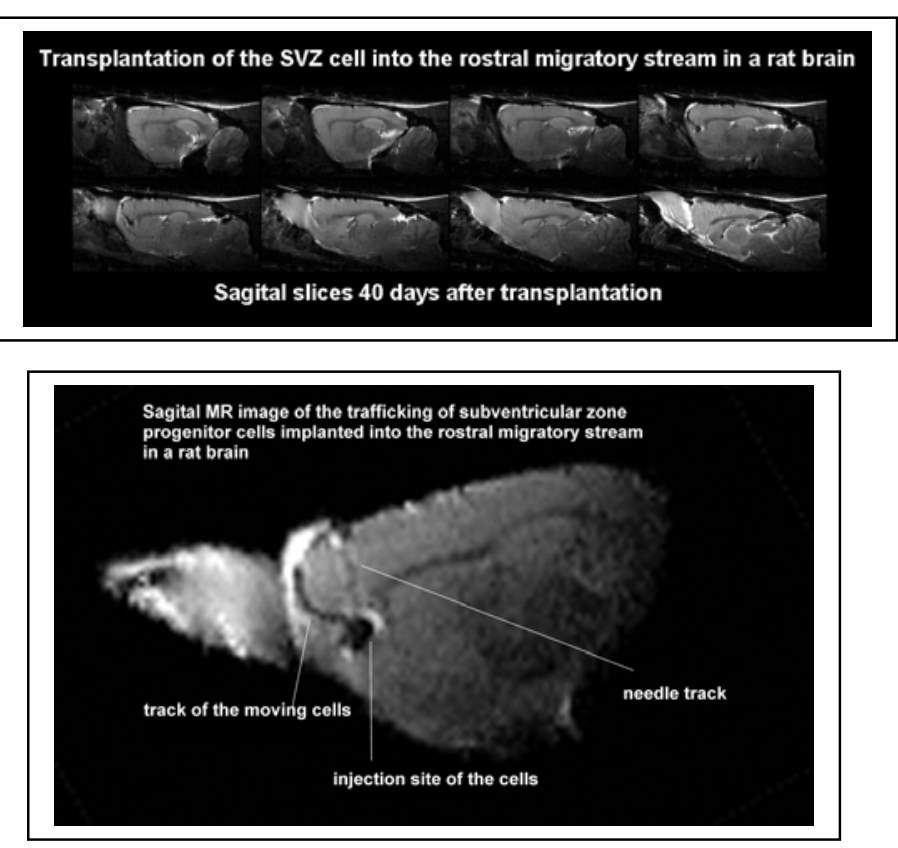

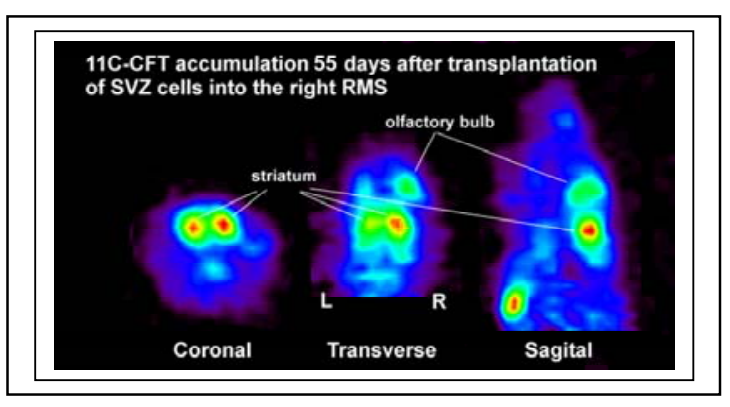

Figure 14. PET study of dopamine transporters 55 days after transplantation with iron labeled SVZ cells into the RMS. Note enhanced accumulation of radioactivity in the olfactory bulb in the transplanted side. This is the same animal as in Fig. 13

Figure 13. Sagital slices of rat brain shows the path of iron labeled SVZ cells transplanted into the rostral migratory stream 40 days after the transplantation. Lower image is an enlargement of the $4^{\text {th }}$ slice above.

\section{Histological analysis}

For histological studies animals were deeply anesthetized with ketamine and xylazine $(90 \mathrm{mg} / \mathrm{kg}$ and $10 \mathrm{mg} / \mathrm{kg}$ correspondingly) and perfused intracardially with heparinized saline followed by $4 \%$ paraformaldehyde (PFA) in $0.1 \mathrm{M}$ phosphate buffered saline, $\mathrm{pH}$ 7.4. The brains were removed, post-fixed in $4 \%$ PFA for 6 hours, equilibrated in $20 \%$ 
sucrose in $0.1 \mathrm{M}$ PBS for cryoprotection and $35 \mu \mathrm{m}$ sections were cut on a freezing microtome. Brain sections were stained for Iron according to the Accustain iron kit staining protocol (Sigma Diagnostics, St-Louis, MO). Figure 15 shows iron-stained cells in a section from rat striatum. Heavily labeled SVZ cells are seen along the needle track although the labeled cells can also be seen at a distance from the needle track. This observation of cell migration is supported by the MR studies (Figure 13) in transplanted rats.

Immunostaining: Endogenous hydrogen peroxidase activity was quenched by treating sections with $3 \%$ peroxide for $30 \mathrm{~min}$. Brain sections were immunostained for tyrosine hydroxylase (TH) (Pel-Freez, Rogers, Arkansas) (dilution 1:500); dopamine and cyclicAMP- associated receptor phosphoprotein (DARPP32) (Research Biochemical International, Natick, MA) (1:20 000); anti-Nestin (provided by Dr. Robert Gross); Btubulin III (Sigma, monoclonal) (dilution, 1:500); Vimentin (VIM, Dakopatts) (1:25); H Tau (microtubuli-associated protein) (Calbiochem, CA) (dilution, 1:100); hKi67 (proliferating cells) (Chemicon) (dilution, 1:200). The sections were preincubated for 30 min in a solution containing 5\% normal goat serum and $0.1 \%$ triton $\mathrm{X}-100$. After that the sections were incubated overnight at $4{ }^{\circ} \mathrm{C}$ in a solution containing $5 \%$ normal goat serum, $0.1 \%$ triton $\mathrm{X}-100$, and the various primary antibodies. As a control for specificity of antibodies, some sections were treated as above except that the primary antibody was omitted from the incubation medium.
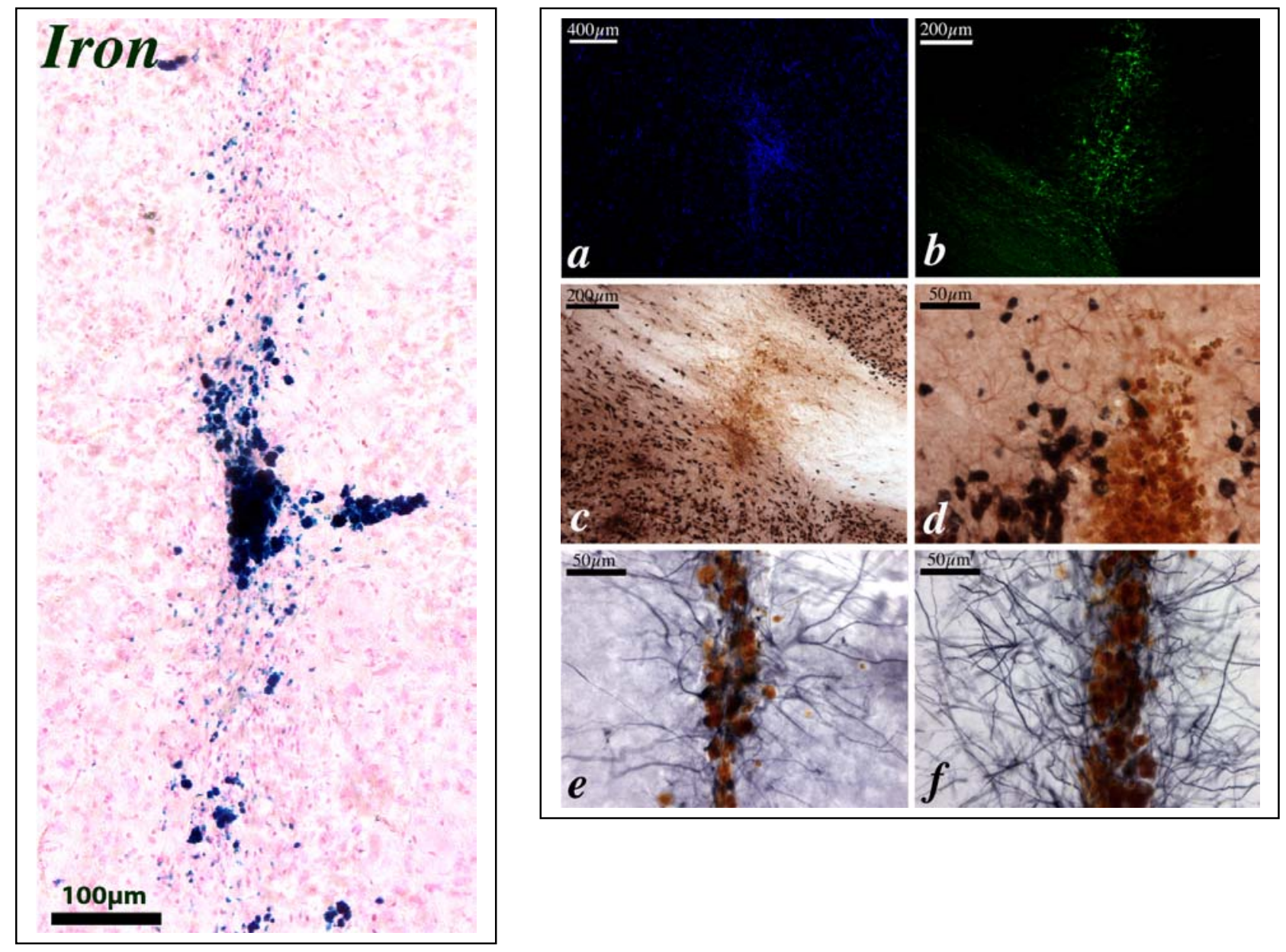
Figure 15. (left) Prussian blue staining of rat striatum ( $35 \mu \mathrm{m}$ section) showing distribution of transplanted, mion labeled SVZ cells. Iron deposits stain blue with potassium ferrocyanide. Cells are then counterstained with pararosanaline; cytoplasm appears light pink. (right) A panel of the immunoassaying; a) DAPI staining showing general nuclei appearance within the needle track clearly indicating a higher concentration of cells in this tissue area. b) fluoro-jade staining illustrating a number of cells undergoing degeneration after transplant. Note that this animal showed the least number of surviving cells of all the animals comprised in this group. c) double immunostaining for the neural marker NeuN (black) and GFAP (brown) depicting the needle track with a few cells which underwent differentiation into astrocytes (arrow) 3 weeks after transplantation into the RMS. d ) Higher magnification of transplant site showing clear astrocytic phenotypes feasibly derived from the graft. e-f) Abundant Nestin positive staining within the transplant illustrating the presence of stem cells 3 weeks post-grafting into the RMS.

\section{Techniques for imaging of PET reporter gene}

Results from the previous studies demonstrate that ${ }^{18} \mathrm{~F}-\mathrm{FDG}$ labeling can be used for short-term PET analyses of transplanted cells. However, long-term studies will require stable expression of reporter molecules, necessary to determine migration and subsequent localization of cells. Methods have already been developed to noninvasively, repetitively and quantitatively assay transgene expression by PET imaging and these techniques can be extended to trace the fate of progenitor cells in brain regions of control and lesioned animals. Application of these tracers will allow for monitoring progenitor cell trafficking, neurotransmitter chemistry and brain function.

Currently, PET reporter gene imaging methods utilize two approaches: transfection of cells with enzymatic or receptor reporter genes. Viral vectors carrying the enzymatic reporter gene are introduced to cells by injection into living tissues or by coculturing with cells in vitro. Enzymatic reporter genes are transcribed and translated into an active enzyme that modifies a radiolabeled probe, trapping it in the transfected cell, and allowing for detection by PET imaging. Cells transfected with receptor reporter genes, express intracellular or membrane receptors that selectively bind radiolabeled ligands. Both of these approaches are quantitative, with the amount of radiolabels accumulated directly related to the level of enzyme or receptor expression. As the positron-emitting radionuclides generate high-energy gamma rays, which are readily visualized in deep tissues with a high level of sensitivity, these methods can be employed to detect transplanted cells as distinct from non-labeled host cells. Since the enzyme or receptor is constitutively expressed, the transfected cells can be detected over time by administration of the radionuclide substrate or ligand.

To date, four genetic reporter genes, type 2 dopamine receptor (D2R) (Gambhir 1999), (Gambhir 2000), (Yu 2000), (MacLaren 1999), (Liang Q 2001), human somatostatin receptor subtype 2A (hSSTr2) (Zinn 2000), (Rogers 2000), thyroid sodium iodide symporter protein (Boland 2000), and herpes simplex virus thymidine kinase (TK) (Gambhir 1998), (Gambhir 2000), (Tjuvajev 1998), (Tjuvajev 1999), have been utilized as stable cellular markers for PET imaging. Their products lead to the selective accumulation of radiotracers that have then been imaged in xenograft tumors, liver and striatum.

Successful strategies have employed the binding of radiolabeled ligands to transgene receptor proteins, including $\mathrm{D}_{2} \mathrm{R}$ (MacLaren 1999) or hSSTr2 (Zinn 2000). 
The transgenes are transported by adenovirus vectors into the cells and are translocated to the nucleus where they are then transcribed into mRNA. The signal is quantitative, with one ligand binding to one receptor. There is no requirement for transport of substrate into cell as the ligands cross the blood-brain barrier and readily bind to the plasma membrane receptors. $\mathrm{D}_{2} \mathrm{R}$ has been imaged with 3-(2'- ${ }^{18} \mathrm{~F}$-fluoroethyl)spiperone (Gambhir 1999), (Gambhir 2000), (MacLaren 1999) and with ${ }^{11} \mathrm{C}$-raclopride (Ogawa 2000). hSSTr2 has been imaged using ${ }^{111}$ In-labeled octreotide (Octreoscan) and ${ }^{99 \mathrm{~m}}$ Tc-labeled P829 (NeoTect/NeoSpect) (Zinn 2000), (Rogers 2000). As signal transduction pathways may be activated by binding of ligands, mutant genes for specific receptors have been utilized to uncouple this pathway as reviewed by MacLaren et al (MacLaren 1999).

Alternatively, radiolabeled probes can be trapped in cells by enzymatic modification, i.e., HSV1-tk (Gambhir 1998), (Gambhir 2000), (Tjuvajev 1998) phosphorylates thymidine, thymidine analogs (i.e., 5-iodo-2'-fluoro-2'deoxy-1-B-Darabino-furanosyl-uracil (Brust 2001) and acycloguanosine analogs (i.e., ganciclovir [GVC]) which are then stably incorporated in DNA (Gambhir 1998), (Gambhir 2000), (Tjuvajev 1998). Though reporter gene technology has been primarily applied to imaging by PET, a recent publication (Ichikawa 2002) describes the utilization of the engineered transferring receptor with a superparamagnetic probe.

\section{Preliminary results of in vitro assay for labeling of Vero and MC26 cells with ${ }^{18} \mathrm{~F}$ - FHBG}

${ }^{18}$ F-FHBG: The synthesis of

$\left[{ }^{18} \mathrm{~F}\right] \mathrm{FHBG}$ was performed

with minor modifications to

procedures reported by

Tjuvajev et al (Tjuvajev 1998)

and by Gambhir et al .

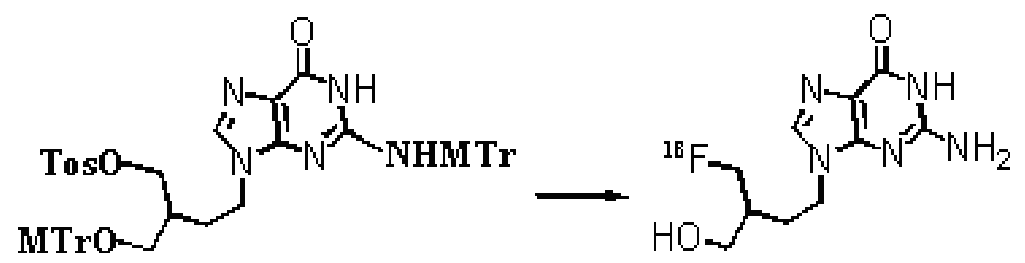

(Gambhir 2000). Briefly, no-carrier added aqueous $\left[{ }^{18} \mathrm{~F}\right] \mathrm{F}^{-}$from the cyclotron was added to a reaction vial containing $3 \pm 0.5 \mathrm{mg}$ potassium carbonate and $10 \pm 1 \mathrm{mg}$ Kryptofix 2.2.2. (Aldrich Chemical Co.). After drying the mixture by acetonitrile $(3 \times 1 \mathrm{ml})$ under nitrogen stream at $110^{\circ} \mathrm{C}$, the precursor tosyl-FHBG $(3.5 \pm 0.5 \mathrm{mg})$ dissolved in $0.5 \mathrm{ml}$ acetonitrile was introduced to the complex. The reaction mixture was heated at $110^{\circ} \mathrm{C}$ for 20 minutes. Upon cooling, the crude product was passed through a Silica Sep-Pak cartridge followed by washing with $15 \% \mathrm{Methanol} /$ dichloromethane $(4 \mathrm{ml})$. After drying, the residue was hydrolyzed with $5 \mathrm{~N} \mathrm{HCl} 0.5 \mathrm{ml}$ for 10 minutes at $110^{\circ} \mathrm{C}$. Upon cooling, the contents were neutralized by $0.5 \mathrm{ml} 5 \mathrm{~N} \mathrm{NaOH}$, followed by HPLC purification on a semipreparative C-18 column ( Waters $\mu$-Bondapak, $300 \mathrm{~mm} \times 3.9 \mathrm{~mm}, 10 \mu \mathrm{m}$ ) washed with $5 \%$ ethanol in water, the fraction containing the product pass through a $0.22-\mu \mathrm{m}$ filter.

Labeling of the cells with ${ }^{18}$ F-FHBG: We have conducted preliminary experiments of radiolabeling with ${ }^{18}$ F-FHBG using Vero (African Green Monkey kidney cell line, ATCC) or MC26 (mouse colon carcinoma cell line, NCI tumor repository) cells. The cells were transfected with herpes simplex virus 1 thymidine kinase mutant gene (HSV1sr39tk), which has been created by substituting seven nucleotides in the wild type gene to 
give rise to five different nonpolar amino acids different from the wild type HSV1-tk. Cells assayed included non-transduced Vero and MC26 cells, Vero and MC26 cells transduced with HSV1-sr39tk, and transduced (HSV1-sr39tk) and non-transduced Vero cells infected with hrR3 virus 24 hours prior to labeling assay.

The hrR3 is a mutant of HSV1 and has the E.coli lacZ gene inserted into the ribonucleotide reductase gene locus. This mutant therefore lacks the viral ribonucleutide reductase gene, which is imperative for viral replication. This renders it "replication defective". Cellular levels of this enzyme which can complement its viral counterpart is exceptionally high in cancers (and negligible in normal cells) and can therefore allow viral repication selectively in cancer cells.

Cells were plated at a concentration of $4 \times 10^{6}$ cells per $100 \mathrm{~mm}$ Petri dish in 10 $\mathrm{ml}$ of DMEM with $10 \% \mathrm{FBS}, 1 \%$ penicillin/streptomycin. For transfection, Vero or MC26 cells were incubated one day after plating with 6 ug of DNA HSV1-sr39tk in 10 $\mathrm{ml}$ serum free DMEM. After 20 hours, the medium was replaced with fresh medium containing FBS. For infection with oncolytic virus hrR3, hrR3 was added 6 hours posttransduction with HSV1-sr39tk. hrR3 was added at 1 x $10^{8}$ P.F.U. (in $10 \mathrm{ml}$ of DMEM with FBS) 24 hours prior to labeling assay
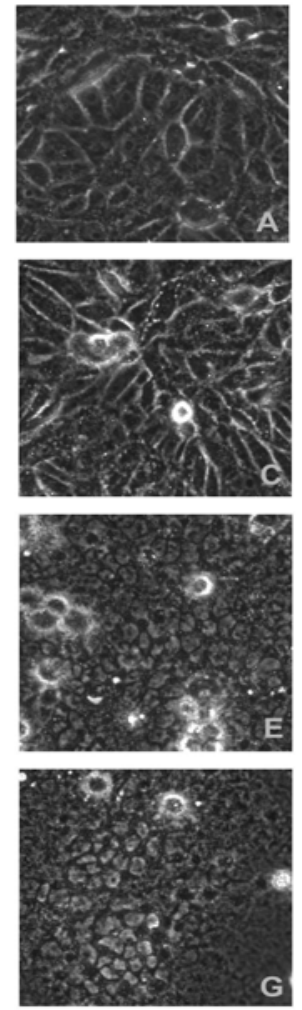

Figure 16. (left)Vero cells before (A) and after ${ }^{18} \mathrm{~F}$ FHBG labeling (B). Vero tk+ (HSV1-sr39tk) before (C) and after ${ }^{18}$ F-FHBG labeling (D). Vero cells infected 27 hours earlier with hrR3 $\left(1 \times 10^{8}\right.$ P.F.U.) before (E) and after ${ }^{18} \mathrm{~F}-\mathrm{FHBG}$ labeling (F). Vero cells tk+ (HSV1-sr39tk), infected 27 hours earlier with hrR3 ( 1 x10 $0^{8}$ P.F.U.) before $(\mathrm{G})$ and after ${ }^{18}$ F-FHBG labeling (H). (below) Fold increase over control cells in each cell conditions.

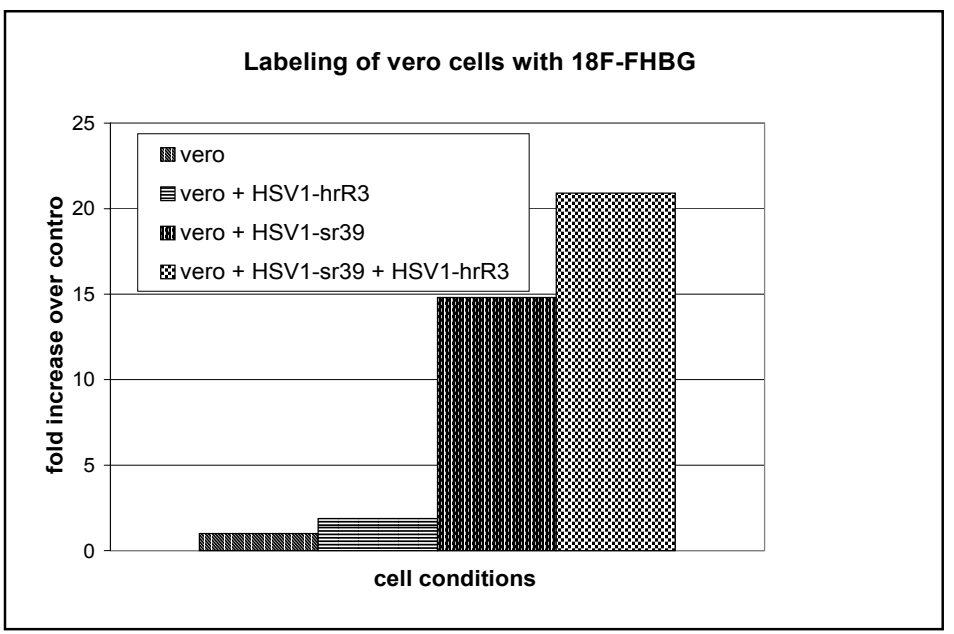

At the time of labeling assay, the cells were adherent and growth was confluence. For labeling, $10 \mathrm{ml}$ of media was removed from dishes and replaced with $10 \mathrm{ml}$ of fresh media containing $\left[{ }^{18} \mathrm{~F}\right] \mathrm{FHBG}(2-215 \mathrm{uCi} / \mathrm{dish})$. The cells were incubated for 3 hours. After incubation with radiolabel, the medium was removed and retained for counting. Cells were washed $(3 \mathrm{X} 4$ $\mathrm{ml}$ ) in fresh medium without radiolabel and each wash retained for counting. The cells were then trypsinized ( $2 \mathrm{ml}$ of $0.1 \%$ trypsin) and suspended in $4 \mathrm{ml}$ of media. Cells were triturated and cell 
counts were obtained utilizing a hemocytometer. The cellular fraction was retained for counting. Amount of label in each fraction was determined using a gamma counter and activity per cell was calculated. Uptake of label in a specific cellular fraction was determined and divided by total cell numbers in that fraction to obtain activity per cell.

The tk+ Vero cells revealed a 15-21 fold increase in ${ }^{18} \mathrm{~F}-\mathrm{FHBG}$ uptake as compared to the non-transduced cells (Fig. 16); those infected with the hrR3 showed an increased uptake in both transduced and non-transduced Vero cells (Fig. 16- see graph of data). These results are similar to those described by Alauddin and Conti (1998) where they show an average of 18.20-fold higher uptake (12.32-23.26 range) into transduced (HSV tk) cells than nontransduced human colon cancer cells (HT-29) after a 3 hour incubation MC26 tk + cells did not show appreciable labeling with ${ }^{18} \mathrm{~F}$-FHBG as compared to the non-transduced MC26 cells. In our studies, nontransduced and tk+ Vero cells looked morphologically similar before (Fig. 16, A and C) and after 3 hour labeling with ${ }^{18}$ F-FHBG (Fig. 16 B and D - see photographs); while non-transduced and tk+ Vero cells infected with hrR3 virus looked rounded at 24 hour post-infection (Fig. $16 \mathrm{E}$ and $\mathrm{G}$, before labeling with ${ }^{18} \mathrm{~F}-\mathrm{FHBG}$ ) and were swollen and appeared to be lysing (Fig. $16 \mathrm{~F}$ and $\mathrm{H}$ ) at 27 hours post-infection (after 3 hours of labeling). Plaques were visible (Fig. $16 \mathrm{~F}$ and $\mathrm{H}$ ) at 27 hour post-infection, after 3 hour labeling with ${ }^{18} \mathrm{~F}-\mathrm{FHBG}$. Photographs were taken with Q-Fire digital camera, 200X.

These preliminary studies show that we can introduce reporter gene into cell and successfully image it with PET radioligands.

\section{Reportable Outcome}

In the following is a list of the most important results obtained during the one-year research effort:

1.The injection site of the cells effects on trafficking. SVZ cells implanted into the striatum moved during 28 days only 1- $2 \mathrm{~mm}$ from the injection site; while SVZ cells transplanted into the rostral migratory stream moved several centimeters toward the olfactory bulb.

2. Transfecting the cells with SPIO-poly-L-lysine complex it is possible to follow longterm migration of the cells.

3. Using SPIO labeled cells it is also possible to illustrate the whole migration path, since part of the cells will die and will be detected in MR imaging because of iron. The front line of the path relates to movable cells.

4. Labeling of the cells with ${ }^{18} \mathrm{~F}$-labeled compounds can be used to verify the transplantation site and a path of fast moving cells.

5. In 40 days SVZ cells transplanted into the rostral migratory stream can differentiate to neurons and astrocytes.

6. Implanted PC12 cells develop into massive tumors after 7 days retention time.

7. Transplantation site effects also on the function of PC12 cells. After transplantation into the RMS tumor growing is not as fast as after transplantation into the striatum. 
8. Large tumor in striatum will effect on dopaminergic function.

9. Activated microglia can be observed both after transplantation of PC12 cells or SVZ cells with PET using ${ }^{11} \mathrm{C}-\mathrm{PK} 11195$.

10. tk + Vero cells has 15-20 fold increase in ${ }^{18} \mathrm{~F}-\mathrm{FHBG}$ uptake compared to nontransduced cells.

\section{Major accomplishments}

By far 3 abstracts have been presented in national and international meetings. In addition 2 more abstracts and at least one manuscript are in process based on the data obtained of this one year funded project.

1. Mary Owen, Iris Y. Chen, Francesca Cicchetti, Christopher Owen, Meixiang Yu, Xukui Wang, Kimmo Jokivarsi, Anna-Liisa Brownell. Monitoring progenitor cell trafficking by PET and MR imaging. Northeast Regional Meeting of the Society for Developmental Biology, Woods Hole, Massachusetts. (Abstract and Poster included).

2. Mary Owen, Jeff Bulte, Francesca Cicchetti, Iris Chen, Christopher Owen, Xukui Wang, Meixiang Yu, Kimmo Jokivarsi, Anna-Liisa Brownell. Development of in vivo imaging techniques for trafficking of subventricular zone neural stem cells. Society for Developmental Biology $62^{\text {nd }}$ Annual Meeting and International Society of Developmental Biologists, Boston, Massachusetts. (Abstract and Poster included).

3. Francesca Cicchetti, Jeff Bulte, Mary Owen, Robert Gross, Y. Iris Chen, Nicolas Lapointe, Meixiang Yu, Xukui Wang, Christopher Owen, Kimmo Jokivarsi, Aparajita Sarkar, Anna-Liisa Brownell. Monitoring the migration of transplanted progenitor cells with PET and MRI. Neuroscience 2003, New Orleans, Lousiana. (Poster included).

4. Mary Owen, Francesca Cicchetti, Jeff Bulte, Robert Gross, Y. Iris Chen, Meixiang $\mathrm{Yu}$, Xukui Wang, Christopher Owen, Anna-Liisa Brownell. Monitoring the migration of transplanted subventricular zone neural progenitor cells with PET and MRI (manuscript in process).

Future Plans: To get this productive and innovative project funded and create collaborative research projects to utilize obtained results especially in cancer research.

\section{Literature cited}

Alauddin, MM., Shahinian, A., Gordon, EM., Bading, JR., Conti, PS. (2001). "Preclinical evaluation of the penciclovir analog 9-(4-[18F]fluoro-3-hydroxymethylbutyl)guanine for in vivo measurement of suicide gene expression with PET." J Nucl Med 42: 1682-90. 
Boland, A., Ricard, M., Opolon, P., Bidart, JM., Yeh, P., Filetti, S., Schlumberger, M., Perricaudet, M. (2000). "Adenovirus-mediated transfer of the thyroid sodium/iodide symporter gene into tumors for a targeted radiotherapy." Cancer Res 60: 3484-3492.

Brownell, A.-L., Livni, E., Galpern, W., Isacson, O (1998). "PET imaging of dopamine terminals in a rat transplant model of Parkinson disease." Ann Neurol 43:387-90.

Brownell, G., Burnham, CA., Stearns, CW., Chesler, DA., Brownell, A-L., Palmer, M. (1989). "Development in high-resolution positron emission tomography at MGH." Int J Img Systems and Technol 1: 207-17.

Brust, P., Haubner R., Friedrich A., Scheunemann M., Anton M., Koufaki ON., Hauses M., Noll S., Noll B., Haberkorn U., Schackert G., Schackert HK., Avril N., Johannsen B. (2001). "Comparison of [18F]FHPG and [124/125I]FIAU for imaging herpes simplex virus type 1 thymidine kinase gene expression." Eur J Nucl Med 28: 721-9.

Bulte, J., Duncan ID, Frank JA. (2002). " In vivo magnetic resonance tracking of magnetically labeled cells after transplantation." J Cereb Blood Flow Metab 22: 899-907.

Cicchetti, F., Brownell A-L., Williams K., Chen Y.I., Livni E., Isacson O. (2002). "Neuroinflammation of the nigrostriatal pathway during progressive 6-OHDA dopamine degeneration in rats monitored by immunohistochemistry and PET imaging." Eur J Neurosci 15: 991-998.

Gambhir, S., Barrio, JR., Herschman, HR., Phelps ME. (1999). "Assays for noninvasive imaging of reporter gene expression." J Nucl Med 26: 481-490.

Gambhir, S., Barrio, JR., Wu, L., Iyer, M., Namavari, M., Satyamurthy, N., Bauer, E., Parrish, C., MacLaren, DC., Borghei, AR., Green, LA., Sharfstein, S., Berk, AJ., Cherry, SR., Phelps, ME., Herschman, HR. (1998). "Imaging of adenoviral-directed herpes simplex virus type 1 thymidine kinase reporter gene expression in mice with radiolabeled ganciclovir." J Nucl Med 39: 2003-2011.

Gambhir, S., Bauer, E., Black, ME., Liang, Q., Kokoris, MS., Barrio, JR., Iyer M, Namavari, M., Phelps, ME., Herschman, HR. (2000). "A mutant herpes simplex virus type 1 thymidine kinase reporter gene shows improved sensitivity for imaging reporter gene expression with positron emission tomography." Proc Natl Acad Sci USA 97: 2785 2790 .

Goldman, S., Luskin MB. (1998). "Strategies utilized by migrating neurons of the postnatal vertebrate forebrain." Trends Neurosci 21: 107-114.

Gritti, A., Parati EA, Cova L, Frolichsthal P, Galli R, Wanke E, Faravelli L, Morassutti DJ, Roisen F, Nickel DD, Vescovi AL. (1996). "Multipotential stem cells from the adult 
mouse brain proliferate and self-renew in response to basic fibroblast growth factor." Journal of Neuroscience 16: 1091-1100.

Hoffman, E., Huang, SC., Phelps, ME. (1979). "Quantitation in positron emission tomography. 1 - Effect of object size." J Comp Assist Tomogr 3: 299-308.

Ichikawa, T., Hogemann D, Saeki Y, Tyminski E, Terada K, Weissleder R, Chiocca EA, Basilion JP. 2002. (2002). "MRI of transgene expression: Correlation to therapeutic gene expression." Neoplasia 4: 523-530.

Kakita, A., Goldman JE. (1999). "Patterns and dynamics of SVZ cell migration in the postnatal forebrain: Monitoring living progenitors in slice preparations." Neuron 23: 46174.

Liang Q, S. N., Barrio JR, Toyokuni T, Phelps MP, Gambhir SS, Herschman HR. (2001). Noninvasive, quantitative imaging in living animals of a mutant dopamine D2 receptor reporter gene in which ligand binding is uncoupled from signal transduction. Gene Ther 8:1490-1498.

Lois, C., Alvarez-Buylla A. (1993). " Proliferating subventricular zone cells in the adult mammalian forebrain can differentiate into neurons and glia." Proc Natl Acad Sci 90: 2074-77.

Lois, C., Alvarez-Buylla A. (1994). "Long-distance neuronal migration in the adult mammalian brain." Science 264: 1145-48.

MacLaren, D., Gambhir, SS., Satyamurthy, N., Barrio, JR., Sharfstein, S., Toyokuni, T., Wu, L., Berk, AJ., Cherry, SR., Phelps, ME., Herschman, HR. . (1999). "Repetitive, noninvasive imaging of the dopamine D2 receptor as a reporter gene in living animals." Gene Ther 6: 785-791.

Melder, R. J., E. D., et al. (1994). "A method for labeling cells for positron emission tomography (PET) studies." J Immunol Meth 175(1): 79-87.

Ng, Y.-K., Lu X, Levitan ES. (2002). " Physical mobilization of secretory vesicles facilitates neuropeptide release by nerve growth factor-differentiated PC12 cells." J Physiol 542: 395-402.

Ogawa, O., Umegaki H, Ishiwata K, Asai Y, Ikari H, Oda K, Toyama H, Ingram DK, Roth GS, Iguchi A, Senda M. (2000). "In vivo imaging of adenovirus-mediated overexpression of dopamine D2 receptors in rat striatum by positron emission tomography." NeuroReport 11: 743-48.

Peng, W., Yu LL, Bao CY, Liao F, Li XS, and Zuo MX. (2002). " Transplanted neuronal precursors migrate and differentiate in the developing mouse brain." Cell Res 12: 223-8. 
Picard-Riera, N., Decker L, Delaresse C, Goude K, Nait-Oumesmar B, Liblau R, PhamDinh D, Baron-Van Evercooren A. (2002). " Experimental autoimmune encephalomyelitis mobilizes neural progenitors from the subventricualr zone to undergo oligodendrogenesis in adult mice." Proc Natl Acad Sci USA 99.

Rogers, B., Zinn, KR., Buchsbaum, DJ. (2000). "Gene transfer strategies for improving radiolabeled peptide imaging and therapy." Q J Nucl Med 44: 208-223.

Shafer, T., Atchison WD. (1991). "Transmitter, ion channel and receptor properties of pheochromocytoma (PC12) cells: a model for neurotoxicological studies." Neurotoxicol 12: 473-92.

Tjuvajev, J., Avril N, Oku T, Sasajima T, Miyagawa T, Joshi R, Safer M, Beattie B, DiResta G, Daghighian F, Augensen F, Koutcher J, Zweit J, Humm J, Larson SM, Finn R, Blasberg R. (1998). "Imaging herpes virus thymidine kinase gene transfer and expression by positron emission tomography." Cancer Res 58: 4333-41.

Tjuvajev, J., Chen SH, Joshi A, Joshi R, Guo ZS, Balatoni J, Ballon D, Koutcher J, Finn R, Woo SL, Blasberg RG. (1999). "Imaging adenoviral-mediated herpes virus thymidine kinase gene transfer and expression in vivo." Cancer Res 59: 5186-93.

Yu, Y., Annala, AJ., Barrio, JR., Toyokuni, T., Satyamurthy, N., Namavari, M., Cherry, SR., Phelps, ME., Herschman, HR., Gambhir, SS. (2000). "Quantification of target gene expression by imaging reporter gene expression in living animals." Nat Med 6: 933-937.

Zinn, K., Buchsbaum, DJ., Chaudhuri, TR., Mountz, JM., Grizzle, WE., Rogers, BE. (2000). "Noninvasive monitoring of gene transfer using a reporter receptor imaged with a high-affinity peptide radiolabeled with 99mTc or 188Re." J Nucl Med 41: 887-895. 
Francesca Cicchetti ${ }^{1}$, Jeff Bulte ${ }^{2}$, Mary Owen ${ }^{3,4}$, Robert Gross ${ }^{5}$, Iris Chen ${ }^{4}$, Nicolas Lapointe ${ }^{1}$, Meixiang $\mathrm{Yu}^{4}$, Xukui Wang ${ }^{4}$, Christopher Owen ${ }^{4}$, Kimmo Jokivarsi ${ }^{4}$, Aparajita Sarkar ${ }^{4}$, Anna-Liisa Brownell ${ }^{4}$

\section{ZINTRODUCTION}

- ell loss within the centat nervous system (CNS), occuring through trauma, disiease or

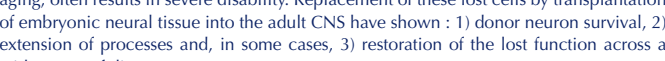

- In the presenece of the mitogens, mixed colonies of the stem cells and progenitior cells

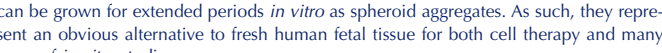

Recently, neural progenitiors with capacity to give rise to all major cell types of the
mature CNS have been isolated from the developing or adult cNS. They become more

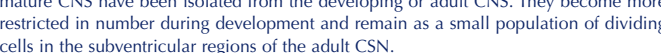

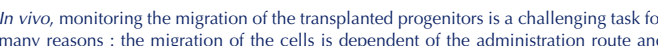
tissue enviromment; the migration rate is is slow (dayys and weeks) and distances are small

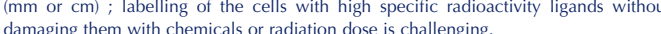
- We investigated the labelling of the SVZ neural progenitor cells with mion (dendrimewith high resolution magnetic resonance imaging using two dififerent administration routes: rostral

\section{MATERIALS \& METHODS} Experimental design

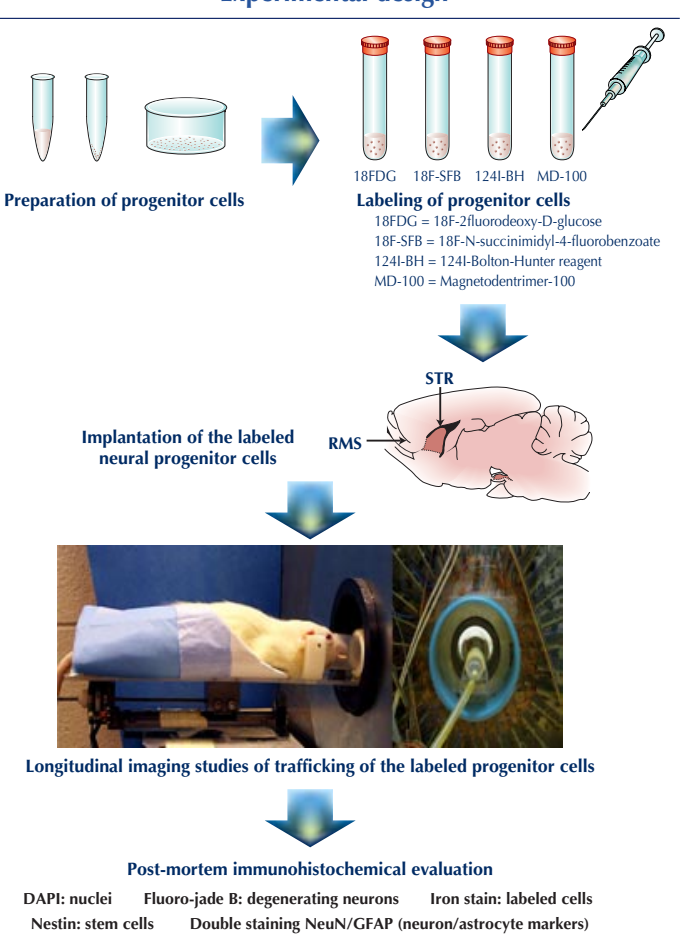

FIGURE 1

${ }^{18} \mathrm{~F}-\mathrm{FDG}$ labeled SVZ neural progenitor cells transplanted into a rat brain

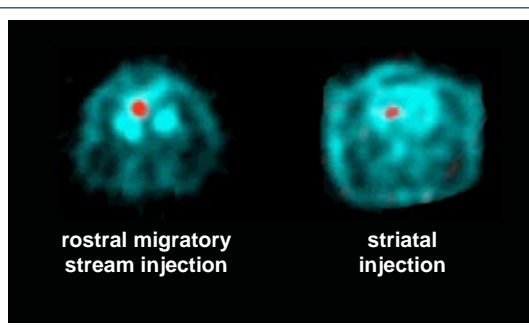

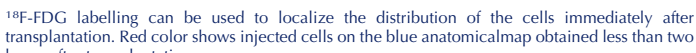
surs aterer transplantation.

FIGURE 2

Transplantation of the SVZ neural progenitor cells into the rostral migratory stream in a rat brain

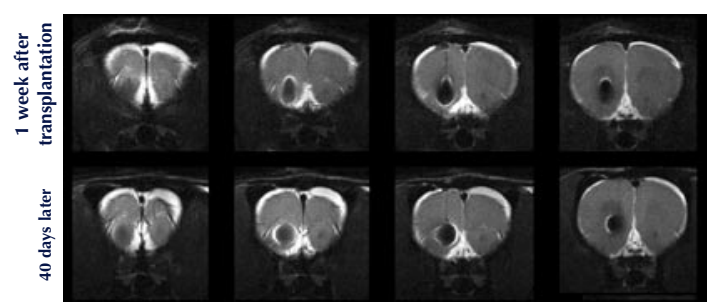

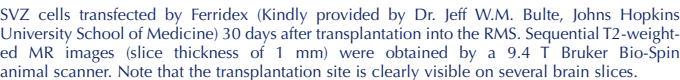

FIGURE 3 Transplantation of the SVZ neural progenitor cell into the rostral migratory stream in a rat brain

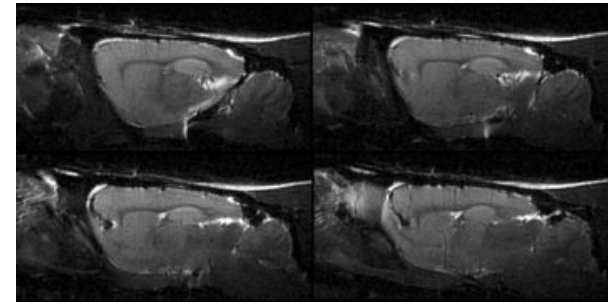

Sagital slices $\mathbf{4 0}$ days after transplantation

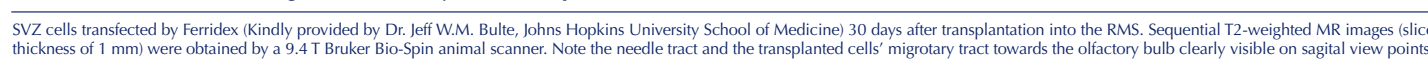
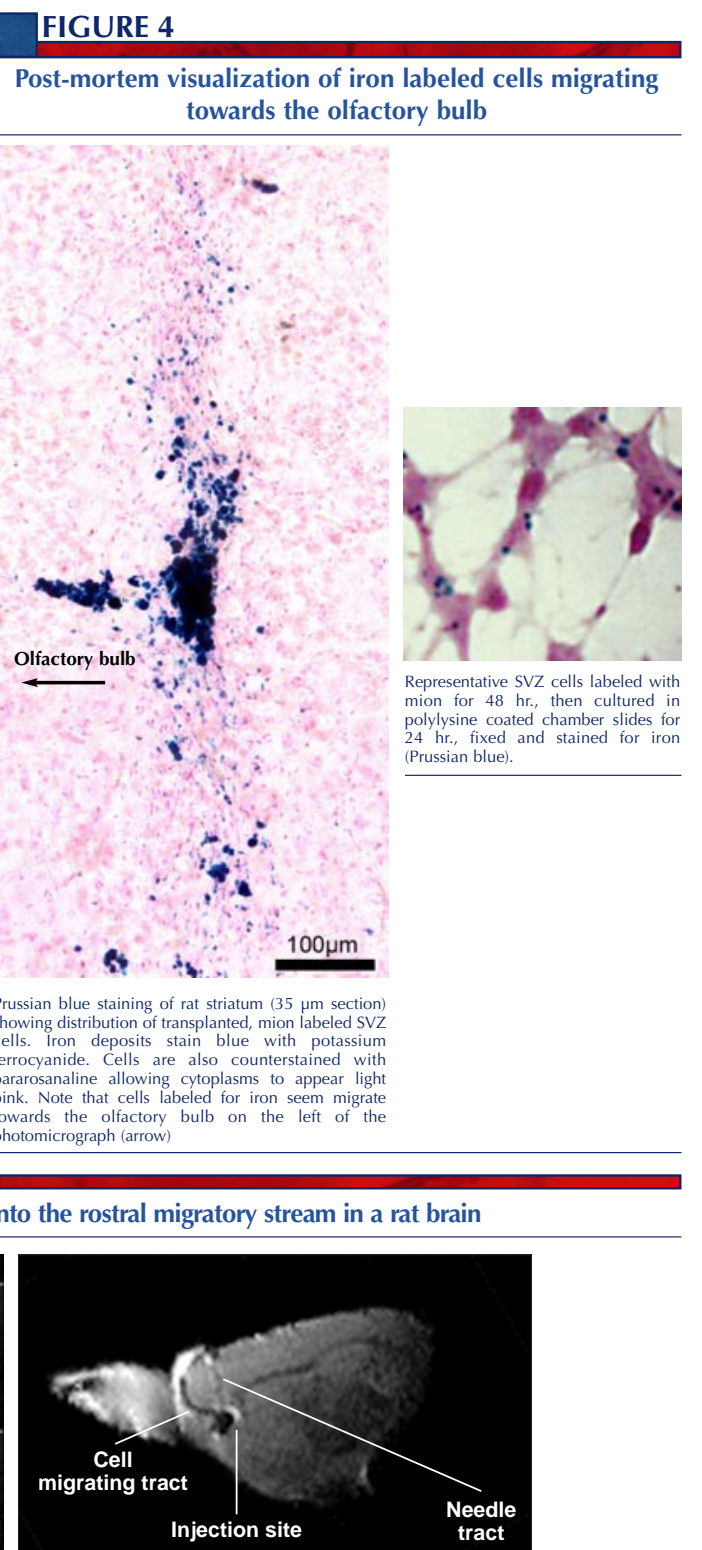

e 2.

$f$

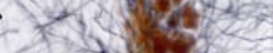

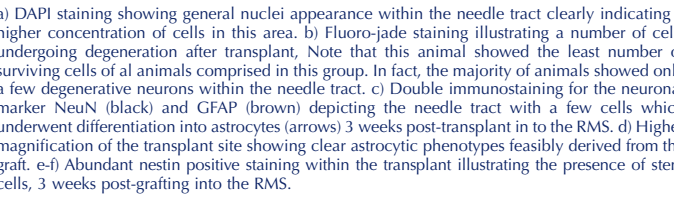

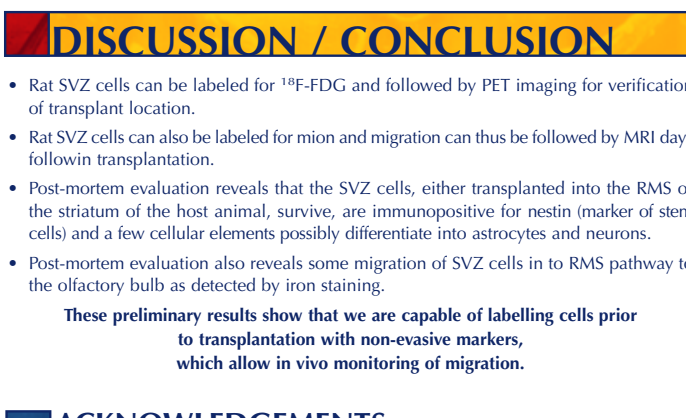

ACKNOWLEDGEMENTS

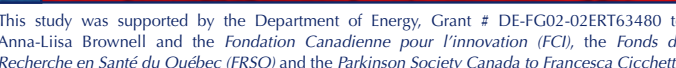

